\title{
In the Streets and at the Table: Civil Society Coordination during Peace Negotiations
}

\author{
Desirée Nilsson, ${ }^{1}$ Isak Svensson, ${ }^{2}$ Barbara Magalhães Teixeira, ${ }^{3}$ \\ Luís Martínez Lorenzo ${ }^{4}$ and Anton Ruus ${ }^{5}$ \\ Department of Peace and Conflict Research, Uppsala University, \\ Box 514, S-751 20 Uppsala, Sweden \\ desiree.nilsson@pcr.uu.se; isak.svensson@pcr.uu.se; \\ barbara.magalhaes_teixeira@svet.lu.se; luis.martinez@pcr.uu.se; \\ anton.ruus.7072@student.uu.se
}

Received 12 April 2019; accepted 8 December 2019

\begin{abstract}
When bringing armed conflicts to a peaceful end, the inclusion of civil society in peacemaking is a vital task. However, whereas previous research on civil society inclusion has made significant advancements, surprisingly little attention has been paid to analyzing how civil resistance and mass action may interact with more elite-driven approaches during peace processes. This study addresses this research gap by examining

1 Desirée Nilsson is an Associate Professor at the Department of Peace and Conflict Research at Uppsala University, Sweden. Her research focuses on conflict resolution and durable peace, with a particular emphasis on multiparty civil wars. She has published in journals such as International Organization, Journal of Conflict Resolution, and Journal of Peace Research.

2 Isak Svensson is a Professor at the Department of Peace and Conflict Research, Uppsala University, Sweden. His three main areas of expertise are international mediation, religion and conflict, and nonviolent conflicts. He has published in journals such as European Journal of International Relations, Journal of Conflict Resolution, and Journal of Peace Research.

3 Barbara Magalhães Teixeira is currently a PhD student in Political Science at Lund University. Her research deals with inclusive peace processes with a special focus on conflicts concerning natural resources.

4 Luís Martínez Lorenzo is a research assistant at the Department of Peace and Conflict Research, Uppsala University. His research interests include mediation, ceasefires, the participation of civil society actors in peace processes, and nonviolent conflicts.

5 Anton Ruus has a Master degree from the Department of Peace and Conflict Research at Uppsala University. His research interests include power sharing, democratization, and civil society in peace processes.
\end{abstract}


the interplay between elite and mass-based civil society approaches in three different peace processes in civil wars in Africa in the post-Cold War period: Liberia, the Central African Republic (CAR), and Burundi. We advance the literature by developing a framework that focuses on coordination of these different efforts and we explore this interplay empirically. With this study, we aim to broaden the research agenda, allowing for future synergies at the research frontier of mass action and the inclusion of civil society in peace processes.

\section{Keywords}

inclusion - civil society - political parties - negotiations - civil war-conflict resolutionmass action - peace talks

When bringing internal armed conflicts to a peaceful end, the inclusion of civil society actors in peacemaking is a vital task. ${ }^{6}$ Yet, there is debate concerning the forms for this participation, and how and in what way civil society actors can be included, both inside and outside of the negotiation table (Cunningham 2013; Paffenholz 2014). ${ }^{7}$ Peace processes in civil wars across the globe present a great variation in the different forms of engagement by civil society actors. Sometimes civil society is engaged at the elite level and, for example, participates alongside the warring actors at the peace talks. Other times the participation is mass-based and can include various forms of protests, demonstrations, or street actions. This article seeks to better understand the interplay between these forms of participation by addressing the following research question: in the context of on-going peace negotiations, how do mass-based approaches of civil society engagement and elite-based approaches interact?

Previous research on the inclusion of civil society actors in peacebuilding has made significant advancements but also suffers from one key shortcoming. There is a growing scholarly recognition of the potential of mass-based, nonviolent civil resistance movements, in terms of short-term achievements (Chenoweth \& Stephan 2011; Nepstad 2011; Schock 2005; Zunes 1994), as well as long-term democratization (Ackerman \& Karatnycky 2005; Celestino \&

6 Acknowledgments: We gratefully acknowledge financial support from the Swedish Research Council (no. 2014-03847), the Folke Bernadotte Academy (no. 17-00297), and the Marianne and Marcus Wallenberg Stiftelse (no. MMW 2013.0025).

7 For a recent discussion on inclusion and exclusion of non-warring actors in peace negotiations, see Paffenholz \& Zartmann (2019). 
Gleditsch 2013). However, surprisingly little attention has been paid to analyzing how civil resistance and mass action may interact with more elite-driven approaches during peace processes. Previous research on civil society inclusion has recognized mass action as a potent form of influence for civil society actors. Indeed, one key finding from Paffenholz's (2010) edited volume on eleven case studies showed that civil society actors could influence peaceful outcomes through mass action. Paffenholz (2014) identifies mass action as one out of nine different modes of participation by civil society in peace negotiations. Yet, overall, the literature on the role of civil society in peacebuilding and the research on civil resistance via mass action have been evolving separately from each other. We think that this discrepancy is part of a larger phenomenon of studying mass actions independently from peace processes. As pointed out by Dudouet: "... the role of civil resistance has been so far barely acknowledged within the peacebuilding literature ...” (2017: 18). Dorff (2019) similarly highlights the need to combine these different perspectives. There is, thus, a potential to better integrate insights from these two areas of research.

While the literature on civil society in peacebuilding has explored different forms of community-driven engagement, as well as workshops in the form of Track II diplomacy (Paffenholz 2014; Pouligny 2005; van Tongeren et al. 2005), more focus is needed on civilian mobilization for mass action. In a recent effort, Cuhadar and Paffenholz (2019) explore the linkages between track-two diplomacy and inclusive peace negotiations. This highlights the need to better understand how different forms of participation may interact with each other. While different forms of Track II diplomacy - including parallel fora are important in terms of creating a link to bargaining at the negotiation table, we primarily focus on the interaction between the elite level and mass-based forms of participation. We know too little about how elite-based and massbased approaches interact and how mass action is sequenced in relation to negotiation attempts at the higher political level.

In this article, we seek to broaden the research agenda in order to overcome this shortcoming. Drawing on the literature on the dynamics of coordination in third-party intervention, we develop a framework that centers on the interplay between mass action and elite-based approaches. Our analysis focuses on how different types of interactions between civil society actors at the table and in the streets manifest themselves during the negotiations. We focus on civil society involvement in the context of peace negotiations between the government and one or more rebel groups in an armed conflict. Hence, the scope condition for this study is the presence of peace negotiations. Given that peace talks take place between the warring parties in a civil war, we seek to better understand the relationship between the involvement of civil society at the 
elite level, for example, as participants at the table, and efforts via some kind of mass action. We do not make any causal claims, but seek to emphasize interesting variations regarding civil society participation in mass and elite initiatives during peace negotiations. To do so, we analyze three peace processes in Africa: Liberia, the Central African Republic (CAR), and Burundi.

\section{Theoretical Framework}

\section{Inclusion and Civil Resistance: Similarities and Differences}

Could there be some merit in marrying together the two separate fields of civil society inclusion and nonviolent mass action? These two areas focus on very similar phenomena: how non-warring actors can influence the dynamics and outcomes of political or violent conflict, without using force or working through established and institutionalized democratic procedures (such as elections). Nevertheless, the two fields have largely been working in different silos. This is unfortunate, we think, as there are several benefits from connecting these literatures.

The two areas of research, albeit separately, have generated important insights into the shape and dynamics of civil society in conflictual contexts. We would like to point to two insights that they share. First, the two fields identify a plethora of ways through which non-warring actors seek to influence their situation. Mass action is one of several modes of civil society inclusion that exist (Paffenholz 2010, 2014). Sharp (1973) listed 198 techniques of civil resistance and, although mass-based demonstrations have dominated the attention of existing literature, there is recognition of the great variety in which civil society engagement may manifest itself. In fact, previous research on civil resistance has shown that relying on different types of techniques, being able to diligently sequence between them, innovating new techniques, and adapting to the context are all key explanations for why nonviolent movements become successful (Ackerman \& Kruegler 1994; Schock 2005).

Second, the two fields have aptly demonstrated the potential and power that lies in the hands of civil society actors. Nonviolent mobilization can contribute to achieving fundamental social change, and may be a more effective strategy for challenging the status quo than relying on violent means (Ackerman \& Kruegler 1994; Chenoweth \& Stephan 2011; Nepstad 2011; Vinthagen 2015). Previous research has also shown that popular-based nonviolent means are more likely to lead to democracy in the longer run (Ackerman \& Karatnycky 2005; Celestino \& Gleditsch 2013; Teorell 2010). 
Yet, there are also differences in regard to the focus adopted. First, the civil society inclusion literature has tended to study the question of impact: what is the effect of civil society inclusion on the content and outcome of peace negotiations (Nilsson 2012, 2018; Wanis-St. John \& Kew 2008). This is, of course, also a central question for the field of nonviolent mass action. Still, scholars within nonviolent mass action have, in addition, taken up interest in exploring the question of why and under what conditions civil resistance occurs (Butcher \& Svensson 2016; Chenoweth \& Ulfelder 2017; Schaftenaar 2017), which is something that has not been a focal point of interest for inclusion scholars.

Second, there is another important difference in emphasis within the two scholarly fields. Whereas research on nonviolent mass action has tended to depart from a movement-based analysis, there is a broader recognition in the civil society inclusion literature that civil society is made up of a diverse set of actors. For example, this area of research differentiates between women's organizations, youth groups, religious actors and non-governmental organizations (Paffenholz 2010; Pouligny 2005; Wanis-St. John \& Kew 2008).

\section{Civil Society Inclusion: Conceptual Framework}

Civil society is a contested concept and can be defined in different ways. Theoretically, we may think of civil society in conflicts as the non-state, nonwarring, actors occupying a space between the realms of official politics, on the one hand, and the realm of family-based communities, on the other. In line with Spurk (2010) and Belloni (2008), civil society is here seen as "separate from the state and political parties and consists of the wide range of voluntary organizations in society such as religious associations, women's organizations, human rights groups, and trade unions" (Nilsson 2012: 246). In addition to civil society actors, we also study the involvement of political parties since these, at least in some cases, may have similar roles as the civil society, but we treat the former as separate from the civil society sphere. Recent works highlight the need to not only study the inclusion of civil society actors, but also more carefully consider the involvement of political parties in peace processes (Nilsson 2012; Ross 2019). Hence, in our analysis, we seek to capture the involvement from a wide range of actors including political parties and various civil society organizations such as women's organizations, youth organizations, and religious actors. ${ }^{8}$ Occasionally, we use the term 'non-warring actors' as an overarching concept to capture the involvement from either civil society actors, political parties, or both.

8 We consider civil society actors that are either domestic or international. 
Notably, we do not include in our definition of political parties those organizations which merely serve as the political branch of a military organization, but only those political parties that are engaging through non-violent means. We recognize that these are not always easy distinctions to be made, and may vary over time, yet, the political branch of a militant organization is often identified. It is important to point out that a preference for one or the other side does not disqualify an actor from being categorized as a civil society actor or a political party. It is not necessarily uncommon that civil society actors or political parties are aligned with one of the belligerent sides. In our empirical analysis, we seek to highlight and problematize such linkages.

Mass action is defined as "campaigns, demonstration, street action, protests, and petitions" in relation to the negotiations, using the definition from Paffenholz (2014: 77). The terminology in previous research is not consistent and alternative terms seeking to capture this set of actions include 'civil resistance,' 'strategic nonviolence', 'nonviolent action', 'people power,' 'contentious politics' and 'nonviolent struggle' (Schock 2003). We use the term 'mass action' to differentiate it from elite-based approaches, which lends itself to inclusion by a selected few. While mass action sometimes is organized by existing civil society organizations, which also invites participation from the broader population, other times it may be less organized. It is important to point out that we only focus on mass action relating to the negotiations, and not demonstrations and campaigns in general. We do not include a numerical threshold but recognize that too small actions will generally not be reported in mass media. The civil resistance literature commonly focuses on sizable instances of mass action, where civilians organize in larger gatherings and through popular campaigns with more than a thousand participants, and where they raise maximalist political demands, including regime change and secession (Chenoweth \& Stephan 2011). In line with Paffenholz (2014), we use a different conceptualization of mass action and are interested in various types of campaigns, demonstrations, or protests, which may also include smaller gatherings. Notably, in terms of the stated goals of those involved, we focus on events of mass action, which concern political negotiations.

\section{Coordination in Peace Processes}

A body of scholarly knowledge exists on the dynamics of coordination in thirdparty intervention (Bhattarai 2016; Crocker, Hampson \& Aall 2001; Fisher 2006; Kriesberg 1996; Nan \& Strimling 2006; Vuković 2012), and the coordination literature is helpful in creating an understanding of how the interaction between the table (elite-based negotiation) and the street (mass action) can unfold. 
We draw three general insights from this literature. First, it is widely recognized in this field of research that in a situation of transformation of social conflict in which a plethora of different actors and organizations are active, coordination is a key aspect in order to understand how the situation develops. It is therefore important to scrutinize not only which actors are active, but also how they interact with each other. Previous research has shown that coordination helps to address a set of problems that can occur in a multiparty conflict. This includes using different resources to work on various aspects of a conflict, increasing the bargaining leverage of the coordinating actors, and creating new entry-points through a more diverse network. Coordination can also increase the efficiency by facilitating the division of labor, as well as enhance the legitimacy of the actors by broadening the number of participants involved. The literature also pinpoints that there are several problems associated with multiparty mediation and that failure to coordinate can create obstacles for effective peace processes. These include passing the buck of responsibility, enhancing the risk of 'forum shopping' between different negotiation tracks, creating misunderstandings, and increasing the risk that different actors work to undermine, rather than strengthen, each other's' efforts. A lack of coordination between actors can lead to mixed messaging, which in turn can increase the gaps in communication and lead to misunderstanding between the parties (Crocker, Hampson \& Aall 2001). In line with these concerns, Kriesberg (1996) identifies how the multiplicity of intermediaries can create obstacles for peacemaking processes such as leading to divergent expectations, the undermining of the policies, and draining on the main parties' attention.

A second important insight that we draw from the coordination literature is that coordination can vary. Nan \& Strimling (2006: 2) define coordination broadly to include "... information sharing, collaborative analysis and strategizing, resource sharing, formal partnerships, and other means of synchronizing and/or integrating activities." Strimling (2006) has developed a useful framework for analyzing this variation by identifying a spectrum of different forms of interactions between third-party actors, ranging from lower to higher levels of intensity. Drawing on Nan \& Strimling (2006) and Strimling (2006: 94), we focus on communication, which is the least ambitious form, largely restricted to information sharing; resource sharing between actors; synchronization of various types of activities and actions; ${ }^{9}$ collaboration which

9 Strimling's (2006) framework uses the overall term cooperation, and groups resource sharing and synchronization of actions together under the umbrella term 'coordination', whereas we treat these as separate categories. 
implies that the parties jointly decide and implement common actions and entails a partnership that can be either ad-hoc or sustained over time; and lastly integration, which is the most ambitious form of interaction in which various aspects of the included actors are combined into one. Obviously, at one end of the spectrum, the units involved in this interaction cease to exist as separate entities and are fully integrated into one.

A third, relevant insight from the coordination literature is differentiating between the efforts that occur simultaneously or sequentially. According to Fisher, "coordination is directed toward increasing complementarity, either simultaneously or sequentially" (2006: 68), italics added. Thus, coordination is about different actors seeking to complement each other's resources in order to achieve needs or goals that they may not achieve individually. The temporal scope of this coordination is important to consider: how coordination may unfold sequentially over time, with one actor's engagement leading to another's, or in parallel processes.

The above three insights from previous research on coordination by peacemaking actors and intermediaries serve as the framework for our analysis of the interplay between elite-based negotiation attempts, on the one hand, and mass action, on the other. Where applicable, we will also highlight some instances where coordination occurs between civil society actors primarily involved at the elite-level.

\section{Methods and Case Selection}

Empirically, we draw on peacemaking efforts in a few peace processes in Africa, following the end of the Cold War, to map out civil society involvement in relation to peace negotiations. Case studies, as argued by Gerring (2004: 349) "... enjoy a natural advantage in research of an exploratory nature." Since we currently have a limited understanding of the interplay between mass action and elite driven-processes, we believe that it is useful to explore a few peace processes in depth, to arrive at some insights that future research can investigate across other contexts. The cases selected - Liberia (2003), CAR (20062013), and Burundi (1998-2000) - have all experienced intra-state armed conflicts active above a threshold of 25 battle-related deaths between a government and one or more rebel groups. To assess if an armed conflict meets this criterion, we rely on data on armed conflicts from the prominent and well-established Uppsala Conflict Data Program (UCDP) (Harbom, Melander \& Wallensteen 2008). These cases have also seen peace negotiations between the government and one or more rebel groups. We define negotiations in line 
with the definition by the UCDP: negotiations are considered to take place if the two main parties in a conflict dyad meet and discuss issues relating to either the incompatibility of the conflict, or conflict behaviors such as ceasefires, withdrawal of troops, or demilitarized zones.

Importantly, we selected cases that include civil society and political party efforts at the elite level, as well as mass-based activities. By selecting cases that display both forms of efforts, we are able to shed light on the interplay between these and the extent to which these are coordinated or not. For each of these cases, we seek to explore if and how civil society actors and political parties have been engaged in mass and elite activities during the peace process and how these approaches may have interacted and overlapped throughout this process. Civil society or political party engagement at the elite level may sometimes occur in parallel to, or in sequence with, mass-based approaches. By elite-based approaches, we refer to activities and processes in which only leaders or representatives of civil society organizations can participate. These include actions such as serving as a participant at the negotiation table (either as observer, full participant, or mediator), partaking in parallel negotiation or deliberation forums and consultation processes, as well as engaging in problem-solving initiatives. Importantly, these are not exclusive categories, and the boundaries between what is mass versus elite action are sometimes blurred. While we use these two overall categories, the range of activities by civil society or political parties that we cover is diverse, including participation at the negotiation table as observers or as full participants, engagement in parallel forums, or mass-based activities (Paffenholz 2014).

For our analysis, we primarily rely on Factiva, a database which includes news items from a wide range of sources including ввс Monitoring, Reuters and AFP, as well as local news media and regional sources such as Africa Research Bulletin and Africa Confidential. We recognize that reliance on news material comes with possible biases, for example, in terms of which type of events get reported (Weidmann 2016). At the same time, it has the advantage of providing a high degree of comparability in the type of material employed across our cases, and news sources are less likely to be influenced by the outcome of those events (for instance, if a peace effort is successful or not). In addition, to complement these news sources and offer more detail, we also consult various case-specific, secondary sources such as reports from the International Crisis Group (ICG), journal articles, and books. We thus consult a wide range of sources to find information about the engagement by civil society actors and political parties during peace negotiations. 


\section{Empirical Analysis: Charting Variations in Elite and Mass Action}

We now turn to discussing empirically how the elite and mass-based approaches interacted in three contemporary African peace processes.

\section{Liberia}

The peace process in Liberia in 2003 saw several examples of mass-based engagement from civil society actors, as well as elite-based participation of both civil society actors and political parties. The Liberian civil war first broke out in 1989 and came to last until 1996 when a peace accord was signed. Former warlord Charles Taylor won the presidential elections of 1997. After several years of repressive rule under Taylor, civil war broke out again in 1999 when the rebel group LURD made their first incursions from neighboring Guinea. Another rebel group, MODEL, later joined the armed struggle and, in the spring of 2003, the two rebel organizations were making significant advancements on the battlefield (Nilsson 2009; Nilsson \& Söderberg Kovacs 2005). Meanwhile, peacemaking efforts occurred to try to end the brutal civil war.

Peace talks between the government and the LURD rebels were initially scheduled to take place in March 2003, but these were postponed. This announcement triggered a series of mass-based actions carried out by different civil society actors, most notably the Women in Peace Building Network (WIPNET). This women's group mobilized a diverse range of participants, and made use of channels such as the radio to summon people to the streets. In particular, they convened the women in the capital by broadcasting, "If you want peace, make it your duty to come to the Monrovia city hall at 8 A.M. Wear white" (Gbowee 2011: 135). Around a thousand women responded to this call, going into the streets to demand a cessation of hostilities and for negotiations to begin between the warring sides (Gbowee 2011: 135; Agence FrancePresse 2003a). In another protest carried out by WIPNET, 100 women marched silently through Monrovia. Their banners read, "We are tired of war" and "Our children must live in peace" (All Africa 2003a). On April 17, WIPNET conducted a sit-in at the gates of the parliament demanding a halt of violence in the country (Gbowee 2011: 138; All Africa 2003a). These actions contributed to build pressure on Taylor's government, who would offer them the chance to speak to him directly and express their demands (Gbowee 2011: 140). Additional actions carried out by WIPNET included a sex strike announced by radio. The intention was to put pressure on the men and was justified by claiming that, as long as fighting continued, no one was innocent, and that the inaction to stop it would make one guilty (Gbowee 2011: 147). The sex strike lasted for a few months. 
Besides WIPNET, other non-combatant actors were mobilizing before the beginning of negotiations. The Inter-Religious Council of Liberia (IRCL) met with the 18 Liberian political parties in an event which brought consensus on calling for immediate negotiations and a ceasefire, as written in their common resolution (All Africa 2003b). In May, another form of collaboration took place as a forum of women leaders was organized by the Mano River Women Peace Network (MARWOPNET) with the objective of building consensus on the way to restore peace in Liberia (All Africa 2003c). In line with this approach, Archbishop Michael K. Francis stressed the need for civil society to seek a common agenda regarding the peace negotiations (All Africa 2003c). In this sense, there was a sequential collaboration between the different non-warring actors.

In June, negotiations between the government, LURD, and MODEL were finally taking place. Simultaneously, different mass-based actions continued to take place in relation to the talks. However, a more elite-driven form of participation was introduced as civil society groups, church representatives and the 18 political parties were present at the table together with the warring actors (Agence France Presse 2003b). In particular, organizations such as MARWOPNET, the Inter-Religious Council of Liberia, and the Liberian Bar Association were granted observer status at the negotiations (Paffenholz 2014; IPTI 2018).

As the negotiations were ongoing, WIPNET organized prayers for peace in Liberia and carried out a series of demonstrations outside of the negotiation room, chanting, "We want peace" (Gbowee 2011: 155; All Africa 2003d). Notably, representatives of the 50,00o Liberian refugees in Ghana demonstrated in front of Taylor's hotel, expressing their tiredness of the conflict (All Africa 2003e). In another event the same month, 100 WIPNET activists, dressed in white, gathered in front of the US embassy in Monrovia and demanded their intervention to put an end to the Liberian conflict (All Africa 2003f). Furthermore, massbased demonstrations were also carried out by civilians in support of the signing of a ceasefire (Agence France Presse 2003c), and by Liberian civil society groups attending the talks, this time protesting against the collapse of a ceasefire agreed by the belligerents (All Africa 2003g). In July, women from WIPNET blocked the entrance of the conference room where negotiations were taking place. The women refused to let the representatives out until they reached a settlement. Although an agreement was not reached that day, this action increased the pressure to move forward with the talks (BBC Monitoring Africa 2003a; 2003b; Gbowee 2011: 161-163; Nilsson 2009; Zanker 2014).

As part of the negotiations, representatives of the political parties and civil society organizations met to draft an agenda for political reform (All Africa 2003e). In particular, this elite-based participation at the talks was focused on 
the organization of presidential elections (All Africa 2003e), and they played a direct role in nominating candidates for a transitional government (IPTI 2018). The civil society actors also shared statements on thematic issues with the combatants, the mediator, and sometimes the press (IPTI 2018). Apart from the formal negotiations, another example of more elite-driven initiatives were the talks between the community of Sant'Egidio and LURD leaders in early August, resulting in the rebels vowing to respect a recently agreed upon ceasefire and to withdraw from Monrovia as the peacekeeping troops arrived (BBC Monitoring Africa 2003c; Agence France Presse 2003d).

Finally, a comprehensive peace agreement was signed in Accra, Ghana on 18 August. This resulted in a significant reduction of the violence in the country over the following years. The agreement included provisions demanded by civil society actors, such as the inclusion of a Ministry of Gender in the transitional government (Accra Agreement 2003; IPTI 2018).

There was a high degree of coordination between the mass-based and the elite-driven initiatives to influence the direction of the peace talks. Illustrating a form of resource sharing, WIPNET declined an offer to participate as observers at the negotiations in order to avoid the impression that they were competing with MARWOPNET or that they mistrusted the latter (Gbowee 2011: 156). This decision can be seen as a form of parallel synchronization since the two women's groups kept separate their involvement, from within and from outside the conference room, respectively. These women's groups agreed to share information on what MARWOPNET heard at the talks, and to collaborate on a daily press release expressing the position of women with a unified voice (Gbowee 2011: 156). Importantly, both groups aimed to address the persistent gender inequalities in Liberia (IPTI 2018), thus sharing a common agenda. In another example of information sharing between the groups, a Women's Forum was organized at the conclusion of the talks to reflect on the negotiations (IPTI 2018).

This coordination from within and outside of the negotiating table took place despite some existing differences between WIPNET and MARWOPNET, which, however, did not prevent them from coordinating their actions in various ways. The members of the latter consisted of an educated elite of women (Moran and Pitcher 2004) which contrasted with the more diverse but mostly non-wealthy, indigenous members of WIPNET (Gbowee 2011: 144; IPTI 2018). Leymah Gbowee, coordinator of WIPNET, admitted that the relationship with MARWOPNET was not easy prior to their decision to coordinate with each other during the peace talks, and that women from MARWOPNET never attended the actions called by WIPNET despite always being invited (Gbowee 2011: 144). 
In addition, it seems that the actors from civil society organizations participating at the elite level occasionally collaborated in their actions. Archbishop Michael K. Francis stressed the need for civil society to seek a common agenda even before the peace negotiations had started (All Africa 2003c). As for the political parties, they also met together with the IRCL before the peace talks to call for negotiations and a ceasefire (All Africa 2003f), showing a common stance and a close collaboration with the inter-religious organization, synchronizing their demands for an end to violence and for peace talks to begin. It is more unclear the extent to which Sant'Egidio coordinated with the other civil society actors. They held a separate meeting with the LURD rebels in Rome demanding respect for a ceasefire (BBC Monitoring Africa $2003 \mathrm{~d}$ ), and previously convened LURD and the government to halt the former's advance on Monrovia for humanitarian reasons (Agence France Presse 2003d). In both events there is no indication that other civilian organizations or political parties participated.

In short, the Liberian case illustrates various forms of coordination between the mass and elite-based participation of civil society actors, particularly by women's groups, as well as occasional collaboration among the participants at the elite level. At least to some degree, WIPNET and MARWOPNET shared information and synchronized their actions from within and from outside of the negotiating table, as well as collaborated on a daily press release. At the elite level, the IRCL together with political parties and other civil society organizations appear to have collaborated sequentially: they met before the launch of the peace talks to develop a common agenda that they would later advocate at the table.

\section{The Central African Republic}

The Central African Republic has seen many conflicts and coups over the years since its independence from France in 1960, until 2003 when the forces of Francois Bozizé overthrew the government of CAR and took over power. As a response to that, in 2006 a coalition of smaller rebel groups united under the name of UFDR (Union of Democratic Forces for Unity) to contest the legitimacy of the government, given their shared understanding of the political and economic marginalization under the new regime. Their biggest claims were that Bozizé carried out exclusionist policies centered only on his own political and ethnic base, while failing to share the wealth with the rest of the country (UCDP 2019).

In the case of the Central African Republic, the interplay between the civil society groups and political parties at different levels is observable through mass actions in the streets and participation of groups at the elite-level in formal negotiations. The population of CAR, having lived through many coups 
and many rebel groups active in different parts of the country, started taking to the streets in response to the escalation of violence between the UFDR and the government. In April 2006, almost immediately after rebel violence started in the north of the country, a women's group started to mobilize for peace. At least 2,00o women marched in the streets of Bangui to protest the increased rebellion in the northwest of the country. Women representing civil servants, women's associations, and women's religious organizations marched to the Presidential Palace and handed over a memorandum to President François Bozizé, in which they "asked the authorities and the rebels to meet and negotiate for peace" (All Africa 2006).

Refusing to listen to the clamor for peace from the streets, the government sought France's support and an increase in their military deployment in the country to fight off the rebels. However, the rebel insurgence carried on, and the protest organized by the women's group was followed by several other protests of different nature and composition, but always mobilizing civil society around calls for an end to violence. President Bozizé started utilizing the platform of civil society discontent towards the violence to promote his own government as a victim of rebel violence. In November, rebels occupied a series of towns in the north of the country and, in response to these events, Bozizé mobilized civil society for protests demanding peace. His goal was to integrate the agenda of civil society and the government around peace and against rebel violence. However, the civil society groups present at the protests were known to have ties with the government, and government officials were also spotted marching with the crowd. Many protesters were seen carrying banners and signs that read "No to war!" Despite these efforts, Bozizé was not successful in his attempt to integrate his agenda with that of civil society, and people soon began to call for the government to take up on a rebel offer to negotiate a settlement to the conflict (Agence France Presse 2006; US Fed News 2006).

The pressure from the streets, at the mass-level, was coupled with pressure from different groups from civil society and political parties at the elite-level in a sequential manner. The protests in the streets played an important role in calling attention to the desire of the population for peace and pressuring the involved parties into negotiations. As a response to that, a Council of Elders led by Pastor Isaac Zokoe, started meeting with the rebels to arrange negotiations. The Council, which consisted of 30 community leaders and human rights campaigners, was formed in 2003 to "negotiate disputes between government and dissidents." They were working on gaining trust from the rebels to facilitate negotiations with the government, signaling to President Bozizé their intention to seek a peaceful resolution to the conflict (Associated Press Newswires 2007a). Following Bozizé's rejection of the rebel group's proposal for 
a national dialogue, and charged by the public mobilization in the streets, the opposition political parties started meeting to discuss how they could design a new proposal and pressure the government for a national dialogue towards peace (Voice of America 2006). Soon enough, after the spread-out mobilization of civil society and political parties across different levels, the government organized a conference on peace and security and invited civil society actors labor unions, NGOs, and religious organizations. Bozizés intention was to be in charge of the conversation and frame the conflict as a regional problem coming from Sudan and Chad instead of addressing the domestic grievances from the rebels. The political parties played an important role in forming a strong and democratic opposition to pressure the government into holding talks with the insurgents (Feniou 2006).

Negotiations eventually started in 2007 under much secrecy, and three peace agreements were reached by December 2008, in which the parties agreed to provisions on ending the hostilities, military power-sharing, DDR, the rebel group's transition into a political party, a government of national unity, and new elections (Associated Press Newswires 2007b; Reuters 2007). In 2008, during the national dialogue mediated by the Center for Humanitarian Dialogue, the government and the UFDR were joined not only by political parties and civil society representatives from unions, religious groups, and other types of organizations, but also by the other rebel groups active in other parts of the country (BBC Monitoring 2008; International Crisis Group 2008; Agence France Presse 2008). The aim of the national dialogue was to achieve a great level of inclusivity and to be able to discuss and agree on a comprehensive peace deal between all levels of society, something never seen before in the country (Xinhua News Agency 2008). Even though many organizations had ties to the government and initially Bozizé saw this as an opportunity to dictate the whole process, the political parties played a significant role in steering the talks and especially making sure that they would result in formal agreements of a binding nature, while the presidential groups were pressuring for an unbinding dialogue (Sguaitamatti 2008).

After signing the peace agreement in 2008 and maintaining his seat in the presidency in the 2010 elections, many groups started contesting the legitimacy of the elections. Discontent was exacerbated by the lack of implementation of the provisions agreed upon in the peace negotiations. In that context, other rebel groups arose to overthrow the government. In 2012, remnants of the UFDR renamed themselves Séléka, and launched a major offensive against the government (UCDP 2019). They stormed the country and rapidly took over four regional cities, and soon closed in on the capital. Given the rapid escalation of 
violence, people took to the streets to protest the rebel offensive and denounce violence.

Once again, civil society mobilized rapidly in pressuring both the government and the rebels for peace initiatives to begin. Two main protests gathered politicians from the opposition and students from the National Association of the Central African Studies (ANECA) in the capital city of Bangui to denounce violence and demand peace (BBC Monitoring Africa 2012). Other protests, this time by government supporters, marched through Bangui from the US embassy chanting for peace. However, things took a violent turn once frustrated demonstrators arrived at the French embassy to ask the former colonial power to help to stop the rebel advance. During this incident windows were broken and the French flag was taken down (Agence France Presse 2012a; Reuters 2012). Women's organizations joined in on the attempt by civil society to mobilize support for peace through mass action by organizing another protest in December 2012. About 300 women marched through the streets of Bangui to urge the rebels from Séléka to stop fighting. The women carried banners and chanted "we want peace in CAR" as they handed a petition to Prime Minister Faustin Archange Touadera (Agence France Presse 2012b).

Following the mobilization of civil society at the mass-level, the opposition political parties quickly organized themselves at the elite-level. They used the political leverage created by the protests to align their agenda towards peace, but they also mobilized themselves around the rebels' demands for Bozizé to step down (AlJazeera 2013; Reuters 2013). During the negotiations, the political parties were responsible for pressuring both warring parties into an agreement on political changes in the government as well as an end to hostilities. They were also responsible for naming the new Prime Minister that would take over the new government (Agence France Presse 2013). The parties signed an agreement in January 2013 under the auspices of the ECOWAS in Gabon, where they agreed to end hostilities and promote a series of political reforms. They also agreed on provisions concerning security guarantees, reconciliation, political prisoners, DDR, and a commitment to use peaceful means (Peacemaker 2019).

The civil society and political party involvement in the peace process in CAR is a vibrant example of a sequential coordination of the actors at different levels. At first, civil society mobilizes at the mass-based level, rallies attention, and calls the parties into action by setting the tone of their demands around peace negotiations. The government tries to capitalize on the commotion generated by civil society by attempting to integrate both movements. It does so by mobilizing its own protests together with civil society organizations known to hold ties with the government. However, the government fails to capitalize on these efforts. Once the protesters started demanding that President Bozizé accept 
peace negotiations with the rebels, they made him accountable for the situation, portraying him as responsible for peace, instead of a victim. On the other hand, the political parties had more success in coordinating their actions at the elite-level with those by civil society at the mass-level. They used the commotion and the momentum created by the protests in the streets to increase their political leverage and pressure the government into peace negotiations as well as substantial governmental reforms.

\section{Burundi}

The Burundian peace process leading up to the Arusha Accords saw a plethora of civil society actors taking action both for and against the peace process. A wide array of such actors, both domestic and international, involved themselves in the process. These included religious actors, youth organizations, women's groups, as well as political parties. Actions taken by these actors were not limited to partaking in official negotiations, but also hosting workshops and parallel forums, consulting with the mediators or the warring parties, and taking to the streets to demonstrate. Although generally considered an example of inclusive negotiations, the civil society involvement was largely limited to elite-level actors, with few examples of mass-based mobilization or avenues through which outside actors could affect the negotiations.

The Burundian civil war fought between 1994 and 2005 pitched several Hutu-oriented rebel groups against the Tutsi-dominated government. In the run up to the conflict, Burundi had embarked on a democratization process. After the assassination of the Hutu president conducted by the Tutsi-dominated army, the country descended into chaos with three rebel groups challenging the government for control of the country: Palipehutu-F NL, Frolina, and CNDD (later also CNDD-FDD).

The years preceding official negotiations were marked with high levels of violence during which domestic non-combatant parties held little influence over the warring actors. International civil society actors however managed to set up initial contacts between the government and CNDD. The initiative led to a series of meetings under the auspices of the Sant'Egidio Community in Rome between September 1996 and April 1997, which paved the way for the later, more inclusive process (Barltrop 2008; International Alert 2012b).

A more comprehensive series of negotiations, later to be known as the Arusha talks, were launched in 1998 and included both CNDD and Frolina. In the early rounds of negotiations, participation of non-warring parties was most notable in the presence of representatives from 17 political parties (International Alert 2012b). These political parties made up the bulk of the 126 participants that partook in the first round of talks in 1998, whereas civil 
society actors were initially not included in the negotiations (International Alert 2012a). The inclusion of these political parties - who later became signatories of the final accord - is an example of elite-level inclusion as it gave a small number of non-warring actors extensive opportunities to influence the negotiations, while the peace process simultaneously remained highly exclusive to the average Burundian. It is worth noting that these parties were often also ethnic based, with some having explicit or implicit ties to one of the warring sides.

In addition to political parties, religious actors and women's groups would later come to join the negotiations. Both international and local religious actors partook in the talks. Matteo Zuppi of the Italian Community of Sant'Egidio participated in the formal negotiations after being named the head of one of the negotiating committees in October 1998 (Xinhua News Agency 1998). Most actors however were limited to less formal channels of influence. Local religious actors, while sporadically included in the formal negotiations, held two separate consultations with lead mediator Nelson Mandela. In one of these consultations, religious actors were part of a 'civil society delegation', which also brought together youth organizations and women's groups in a collaborative action to influence the process away from the negotiation table. These consultative meetings also offered a larger segment of civil society the opportunity to voice their opinions compared to the formal inclusion that was mainly offered political parties (BBC Monitoring Africa 2000c; BBC Monitoring Africa 2oood). Hence, in this case the collaborative action occurred between civil society actors which mainly engaged in elite-based approaches, rather than between the elite and mass-based level.

Women's formal participation increased as the Arusha process progressed. Initially, a few women were offered temporary observer status after women demanded female representation in mid-1998 (International Alert 2012; Xinhua News Agency 1998). Additional women were included in the negotiating parties' delegations, but these female participants did not advocate women's rights or issues specifically, as they followed the agenda of their respective political parties (Daley 2007). Women's formal participation would eventually be expanded and made permanent in January 2000, when seven women were given observer roles at the table (Anderson 2016). A substantial opportunity to influence the negotiations came towards the end of the Arusha process when an All-Party Burundi's Women's Peace Conference was initiated parallel to the ongoing negotiations. The parallel conference brought together 50 women of various backgrounds, including the political parties and armed movements, and allowed them to formulate proposals for integrating a gender dimension in the final peace accord, again expanding the segment of civil society that 
could affect the negotiations (International Alert 2012a; 2012b). Despite the conference opening up the peace talks to more women, it still fell short of providing a channel for the great mass of Burundian women to affect the Arusha talks. Many of these writings were eventually included in the final document signed in August 2002 (Daley 2007).

A final way in which Burundian civil society actors tried to influence the negotiations were the protests hosted in Bujumbura by a small group of civil society actors, headed by a splinter group of the UPRONA party under the leadership of Charles Mukasi. The protests were dismissive of the ongoing peace process and opposed to the government negotiating with some of the warring factions. At least three of these protests were held in the year 2000 (Associated Press Newswires 2000; BBC Monitoring Africa 2000a, 200ob). Although the number of individuals involved in these protests was limited, they constitute an example of collaboration between different types of civil society actors, and the most clearly mass-based civil society events recorded during the peace process.

The Arusha process thus offers several examples of how different civil society actors mobilized to influence the negotiations. At the formal talks, political parties collaborated by forming coalitions roughly following the ethnic line that permeated the conflict (BBC Monitoring Africa 1999). The consultative meetings in which various branches of civil society participated can be seen as a coordinated effort trying to influence the negotiations. Women's groups, in particular, utilized several different channels to shape the peace process (Inclusive Peace 2018). The sequence of these actions illustrates an increasingly strong position from where women's groups could seek to influence the peace process: from meeting separately with the mediator to observing the talks and developing independent suggestions in parallel forums. The All-Party Burundi's Women's Peace Conference displays an integrated level of coordinated action, as women coordinated under a body separate from their previous alignments (BBC Monitoring Africa 200oc; Anderson 2016; International Alert 2012a). Still, the coordination of women's groups was seemingly only present within the elite level of civil society, with no independent mass action having been recorded. The bellicose mass actions in Bujumbura however contradicted the ambitions of other civil society actors. It showcased both the diversity of opinions that existed in the Burundian society at the time, and a possible disunity between the actors involved on the elite and the mass level. Hence, to the extent that coordination occurred during the Burundian peace process, this was largely taking place at the elite-level, and did not involve massbased actions. 


\section{Discussion and Avenues for Future Research}

How do mass-based approaches of civil society and political party engagement and elite-based approaches interact? To what extent do these efforts occur simultaneously or sequentially? What forms of coordination, if any, between elite and mass-based approaches do we see in these cases? There are several important points that can be derived from these case studies.

First, several insights can be reached in regard to the sequencing of mass action and elite-based involvement. Civil society actors can mount pressure on the belligerent parties to make necessary concessions and progress towards a negotiated end to the conflict, as women's organizations pushed for in the Liberian case. Thus, mass action can pave the way for formal negotiations at the elite-level. Yet, the interplay between the elite-based attempts and the mass action in our cases was more dynamic than a strict sequential analysis would lead us to expect. In fact, our analysis suggests that it may be important for the development of the peace processes that the mass action (or at least the potential for such action) is maintained throughout the negotiation process in order to preserve a sense of urgency among the negotiators seeking to carve out an agreement. Mass-based approaches have the potential to push the negotiators into taking publicly costly actions that can bring them closer to an agreement. They can do this by enhancing the sense of urgency to settle the conflict, as the perceived costs of continuous conflict are seen as too high. In Liberia, the women's organization retained their presence outside of the premises where the negotiations took place and, in one instance, also exerted a more direct pressure on the parties. At the same time, elite-based approaches have certain advantages: being able to work more discretely, building up trust over time, and negotiating concrete solutions.

Moreover, civil society organizations can not only mount pressure for a peaceful solution, but also serve as an obstacle against such a solution: civil society can challenge concessions and agreements reached at the negotiations. In the case of Burundi, there were several voices arising from the sphere of the civil society and political parties challenging the peace processes and seeking their end. Hence, the specific dynamics and the manner in which mass action will influence the elite level is likely to be dependent on the agenda of those engaging in mass action, and on the extent to which it aligns with the interests of those at the negotiation table.

Second, the coordination taking place between the mass- and elite-level, in the cases explored in this study, often takes place between civil society organizations of the same category. In Liberia, the women organizations were able to 
create coordination and collaboration between the mass-based and elite-level actions. Yet, this type of coordination between elites and masses did not cut across different sectors of society to the same extent. For example, this type of coordination did not take place between women and religious actors, political parties, or trade unions on different levels. In CAR, political parties partook in the early demonstrations calling for an end to violence, and later participated on the elite level as well. When collaboration between different types of actors occur, this is mainly seen at one level, as illustrated by the consultation talks in Burundi.

Third, whether mass-based and elite-based approaches occur in sequence or parallel to each other may come with particular benefits for the peace process. Mass-based approaches may serve to increase the legitimacy of the elite-based approaches, demonstrating that civil society indeed represents a significant position in the general public. In Liberia, mass-based action seems to have created openings for more forms of inclusion, creating a channel for the broader public to claim influence, whereas elite-based approaches were opened, by their nature, only to a few. In contrast, in the case of Burundi, several different types of actors engaged in the peace process without pressure from mass movements. In this case, political parties, women's organizations, religious actors, and youth movements all exerted a degree of influence on the peace process through a variety of different actions and modes of inclusion.

Fourth, all three cases demonstrate in various ways the usefulness of our analytical framework. The cases to varying degrees displayed different forms of coordination, including collaboration, communication, resource sharing, and synchronization. We also saw evidence of sequencing between mass and elite involvement. Hence, our framework appears to be fruitful for a better understanding of the interplay between elite and mass approaches. Future research should explore this in other empirical contexts, and study how coordination influences the progress and success of peace processes.

Our investigation also demonstrates that regardless of the form of participation, it is important to consider if a particular civil society group or political party is linked to, and shares the agenda of the warring parties. Civil society is commonly defined as being separate from both the state and private businesses - civil society is also distinct from the political sphere of political parties (Spurk 2010). The "independent" characteristic is what confers to it the "social capital" that is often seen as bringing legitimacy to a political process (Putnam 200o). However, in the case of CAR, civil society had ties to the government, and the President was trying to use the former's "social capital" for his own interests. It is often difficult to assert ties between civil society 
organizations and warring parties based solely on "alignment of interests." Civil society and rebel groups can be advocating for a democratic transition during a peace process, for example, without having close ties between them. Civil society organizations also navigate a difficult political space of representation without political powers and therefore rely on the state apparatus to operate. They need a license, they need funding, and they need to create relationships with political actors to press forward with their demands.

On a more general level, our analysis points to the fruitfulness of exploring the interplay between mass- and elite-level actors in peace processes. As this research is at an early stage, more work needs to be done on examining how this interplay unfolds. This line of research can contribute to opening up what so far can be seen as a 'black box' of civil society engagement in peace processes, by taking a dynamic perspective on the organizational relationships. This can help to fill a larger lacuna in peace and conflict research; previous research in this area has mainly focused on the actors carrying arms (governments, rebels and outside countries), while less attention has been paid to primarily non-violent actors. In a modest but important manner, the present study helps to alleviate this by showing the usefulness of adopting a broader scope in the analysis of peace processes. This study has demonstrated that coordination can serve as a useful framework to study the interaction between mass-based and elite-based approaches. Yet, it is often very difficult to assert when civil society organizations are coordinating their actions across different levels during a peace process, and future research should hence study these processes more in-depth and explore the extent to which our findings can be generalized to other contexts. The vibrancy of civil society may vary across countries and political settings, and this could be of importance for civil society's ability to engage in the first place.

Let us end by mentioning briefly some of the policy implications that can be drawn from this research. The overall insight from this study is that the question of coordination is key, and that coordination may manifest itself in different forms. This observation can help policy makers - including external third-party actors and organizations - engaged in seeking peaceful resolution of armed conflict, to develop their policies on how to work with creating linkages between mass action and elite-based negotiations. Moreover, analyzing the interplay between these forms of participation can help to create a deeper appreciation of the variety, diversity, and vibrancy of civil society. Different actors can be important at different stages of the process, and thus the diversity of civil society actors should be encouraged and supported. 


\section{References}

Ackerman, Peter and Christopher Kruegler (1994). Strategic Nonviolent Conflict: The Dynamics of People Power in the Twenthieth Century. Westport, CT: Praeger.

Ackerman, Peter and Adrian Karatnycky (2005). How Freedom Is Won - from Civic Resistance to Durable Democracy. New York: Freedom House.

Agence France Presse (2003a). "Liberian women call for cessation of hostilities and peace talks."

Agence France Presse (2003b). "Taylor's war crimes indictment affects Liberia peace talks in Ghana."

Agence France Presse (2003c). "Landmark truce pact draws mixed reactions in Liberia." Agence France Presse (2003d). "Italian religious community with role in Liberia talks hails peace deal."

Agence France Presse (2006). "Central African president accuses Sudan of supporting rebels."

Agence France Presse (2008). "Dialogue en Centrafrique: quatre personnalités pour assister Pierre Buyoya."

Agence France Presse (2012a). "C. Africa rebels demand surrender as protesters turn on France."

Agence France Presse (2012b). "US evacuates C. Africa embassy as alarm grows over rebels."

Agence France Presse (2013). "Central African opposition names Tiangaye as new PM." All Africa (2003a). "Group Calls for International Stabilization Force."

All Africa (2003b). "Gov't, Lurd Must Cease Fire, Religious Council, Political Parties Stress."

All Africa (2003c). "Bishop Francis, Captan Want One Agenda at Peace Talks."

All Africa (2003d). "TWP Sets Goals for Akosombo."

All Africa (2003e). "Roundtable Deliberations Start at Liberian Talks."

All Africa (2003f). "Government Recaptures Key Port on Eve of Ceasefire."

All Africa (2003g). "Irate NGos Reps Besiege M-Plaza."

All Africa (2006). "Women Lobby for Peace."

Al Jazeera (2013). "CAR war of words heats up amid talks."

Anderson, Miriam J. (2016). Windows of Opportunity: How Women Seize Peace Negotiations for Political Change. Oxford: Oxford Scholarship Online. DoI: 10.1093/ acprof:oso/9780190239534.001.0001

Associated Press Newswires (2000). "Burundi's Tutsis protest peace talks with Hutu rebels."

Associated Press Newswires (2007a). "Central African Republic mediators say government planning to meet with rebels." 
Associated Press Newswires (2007b). "Central African nation to sign peace deal with rebels."

Barltrop, Richard (2008). "The Negotiation of Security Issues in the Burundi Peace Talks." Centre for Humanitarian Dialogue. London: Paul Green Printing. At: https: //www.files.ethz.ch/isn/95072/HD\%2oCentre\%2oNegDis\%2oBurundi\%2O Country\%2oStudy\%2OPDF.pdf.

BBC Monitoring Africa (1999). "Minister welcomes new political alignments." December 14 .

BBC Monitoring Africa (200oa). "Eight leaders of protest march in Bujumbura arrested." $B B C$ Monitoring Africa (20oob). "Security forces break up anti-peace talks' demo, arrest 10."

BBC Monitoring Africa (200oc). "Civic Leaders to Hold Talks with Mandela on Peace Process." 29 May.

$B B C$ Monitoring Africa (20ood). "Mediator Mandela Views Army Reluctance to Integrate Rebels as Setback."

BBC Monitoring Africa (200oe). "Opposition party dismisses Arusha peace agreement." $B B C$ Monitoring Africa (2003a). "Liberian women hold hostage delegates attending regional peace talks."

BBC Monitoring Africa (2003b). "Paper hails Liberian women for holding peace talks delegates 'hostage'."

$B B C$ Monitoring Africa (2003c). "Liberian rebels, in Rome, vow to respect ceasefire."

$B B C$ Monitoring (2008). "Central African leaders agree on consensus government as talks conclude."

$B B C$ Monitoring (2012). "Central African MPs march in Bangui as rebels take another northern town."

Belloni, Roberto (2008). "Civil Society in War-to-Democracy Transitions," in Anna K. Jarstad and Timothy D. Sisk, editors, From War to Democracy: Dilemmas of Peacebuilding. Cambridge: Cambridge University Press, 182-210.

Bhattarai, Prakash (2016). "The Impact of Relationship Dynamics on Third-Party Coordination:Perceptions of Third-Party Practitioners in Nepal and the Philippines.” International Negotiation 21, 1: 43-74.

Butcher, Charles and Isak Svensson (2016). "Manufacturing Dissent: Modernization and the Onset of Major Nonviolent Resistance Campaigns." Journal of Conflict Resolution 6o, 2: 311-339.

Celestino, Mauricio Rivera and Kristian Skrede Gleditsch (2013). "Fresh Carnations or All Thorn, No Rose? Nonviolent Campaigns and Transitions in Autocracies." Journal of Peace Research 50, 3: 385-400.

Chenoweth, Erica and Maria J. Stephan (2011). Why Civil Resistance Works: The Strategic Logic of Nonviolent Conflict. New York: Columbia University Press. 
Chenoweth, Erica and Jay Ulfelder (2017). "Can Structural Conditions Explain the Onset of Nonviolent Uprisings?" Journal of Conflict Resolution 61, 2: 298-324.

Crocker, Chester A., Fen Osler Hampson and Pamela Aall (2001). "A Crowded Stage: Liabilities and Benefits of Multiparty Mediation." International Studies Perspectives 2: $5^{1-67}$.

Cuhadar, Esra and Thania Paffenholz (2019). "Transfer 2.0: Applying the Concept of Transfer from Track-Two Workshops to Inclusive Peace Negotiations." International Studies Review. At: https://doi.org/10.1093/isr/vizo31.

Cunningham, David (2013). "Who Should Be at the Table?: Veto Players and Peace Processes in Civil War." Penn State Journal of Law \& International Affairs 2, 1: 38-47.

Daley, Patricia (2007). "The Burundi Peace Negotiations: An African Experience of Peace-Making." Review of African Political Economy 34, 112: 333-352.

Dorff, Cassy (2019). "Violent and Nonviolent Resistance in Contexts of Prolonged Crisis: The Civilian Perspective." Journal of Global Security Studies 4, 2: 286-291.

Dudouet, Véronique (2017). "Powering to Peace: Integrated Civil Resistance and Peacebuilding Strategies." ICNC Special Series, 1.

Fisher, Ronald J. (2006). "Coordination between Track Two and Track One Diplomacy in Successful Cases of Prenegotiation." International Negotiation 11, 1: 65-89.

Gbowee, Leymah (2011). Mighty Be Our Powers: How Sisterhood, Prayer, and Sex Changed a Nation at War. Philadephia PA: Beast Books.

Gerring, John (2004). "What Is a Case Study and What Is It Good For?" American Political Science Review 98, 2: 341-354.

Glifford, Paul (1995). The Christian Churches and the Democratisation of Africa. Leiden: E. J. Brill.

Harbom, Lotta; Erik Melander and Peter Wallensteen (2008). "Dyadic Dimensions of Armed Conflict, 1946-2007." Journal of Peace Research 45, 5: 697-710.

International Alert (2012a). "Women's political participation and economic empowerment in post-conflict countries - Lessons from the Great Lakes region in Africa." At: https://www.international-alert.org/sites/default/files/publications/2012o9Wome nEmpowermentEN_o.pdf.

International Alert (2012b). "A la conquête de la parole: La participation des femmes dans la transition démocratique au Burundi." At: https://www.international-alert .org/sites/default/files/publications/201209ParticipationFemmesBurundi-FR.pdf.

Inclusive Peace (2018). "Women in Peace \& Transition Processes. Burundi (1996-2014)." Geneva: Inclusive Peace and Transition Initiative. At: https://repository.graduate institute.ch/record/29786o.

International Crisis Group (2008). "Central African Republic: Keeping the Dialogue Alive." At: https://www.crisisgroup.org/africa/central-africa/central-african-republic /central-african-republic-keeping-dialogue-alive. 
Kriesberg, Louis (1996). "Coordinating Intermediary Peace Efforts." Negotiation Journal 12, 4: 341-352.

Nan, Susan Allen and Andrea Strimling (2006). "Coordination in Conflict Prevention, Conflict Resolution and Peace Building." International Negotiation 11, 1: 1-6.

Nepstad, Sharon Erickson (2011). Nonviolent Revolutions: Civil Resistance in the Late 2oth Century. New York: Oxford University Press.

Nilsson, Desirée (2009). “Crafting a Secure Peace: Evaluating the Liberia Comprehensive Peace Accord." Uppsala \& New York: Uppsala University \& the Mediation Support Unit, Department of Political Affairs, the United Nations.

Nilsson, Desirée (2012). "Anchoring the Peace: Civil Society Actors in Peace Accords and Durable Peace." International Interactions 38, 2: 243-266.

Nilsson, Desirée and Mimmi Söderberg Kovacs (2005). "Breaking the Cycle of Violence? Promises and Pitfalls of the Liberian Peace Process." Civil Wars 7, 4: 396-414.

Nilsson, Manuela (2018). "Civil Society Actors in Peace Negotiations in Central America." Journal of Civil Society: 1-18.

Paffenholz, Thania, editor (2010). Civil Society \& Peacebuilding: A Critical Assessment. Boulder: Lynne Rienner Publishers.

Paffenholz, Thania (2014). "Civil Society and Peace Negotiations: Beyond the Inclusion - Exclusion Dichotomy." Negotiation Journal 30: 69-91.

Paffenholz, Thania and I. William Zartman (2019). "Inclusive Peace Negotiations from a Neglected Topic to New Hype." International Negotiation 24, 1: 1-6.

Peacemaker (2019). "Accord politique de Libreville sur la résolution de la crise politicosécuritaire en République Centrafricaine.” United Nations Peacemaker. At: https: //peacemaker.un.org/centrafriqueaccordpolitique2013.

Pouligny, Béatrice (2005). "Civil Society and Post-Conflict Peacebuilding: Ambiguities of International Programmes Aimed at Building 'New' Societies." Security Dialogue 36, 4: 495-510.

Putnam, Robert D. (2000). Bowling Alone: The Collapse and Revival of American Community. New York: Simon \& Schuster.

Reuters (2000). "Burundi opposition leader arrested in demonstration."

Reuters (2007). "UPDATE 2-Central African govt signs peace accord with rebels."

Reuters (2012). "UPDATE 4-CAR wants French help as rebels close in on capital."

Reuters (2013). "UPDATE 2-Central African Republic ceasefire urged as talks begin."

Ross, Nicholas (2019). "A Representative Peace? Opposition Political Parties in Peace Negotiations." International Negotiation 24, 1: 7-37.

Schaftenaar, Susanne (2017). "How (Wo)Men Rebel: Exploring the Effect of Gender Equality on Nonviolent and Armed Conflict Onset." Journal of Peace Research 54, 6: $762-776$. 
Schock, Kurt (2005). UnarmedInsurrection:People Power Movements in Nondemocracies. Minneapolis: University of Minnesota Press.

Sguaitamatti, Damiano (2008). "Central African Republic, Inclusive Political Dialog (Pre-talks only)" in Unpacking the Mystery of Mediation in African Peace Processes. At: https://www.swisspeace.ch/fileadmin/user_upload/Media/Publications/Jour nals_Articles/Aberg_Annika_Unpacking_the_Mystery_of_Mediation.pdf.

Sharp, Gene (1973). The Politics of Nonviolent Action. Boston: Porter Sargent Publisher. Spurk, Christoph (2010). "Understanding Civil Society," in Thania Paffenholz, editor, Civil Society \& Peacebuilding: A Critical Assessment. Boulder: Lynne Rienner Publishers $\left(3^{-27}\right)$.

Strimling, Andrea (2006). "Stepping out of the Tracks: Cooperation between Official Diplomats and Private Facilitators." International Negotiation 11, 1: 91-127.

Teorell, Jan (2010). Determinants of Democratization: Explaining Regime Change in the World, 1972-2006. Cambridge: Cambridge University Press.

US Fed News (2006). "VOA News: CAR Marchers Urge End to Rebel Violence."

van Tongeren, Paul, Malin Brenk, Marte Hellema and Juliette Verhoeven, editors (2005). People Building Peace Ii: Successful Stories of Civil Society. London: Lynne Rienner Publishers.

Vinthagen, Stellan (2015). A Theory of Nonviolent Action: How Civil Resistance Works. London: Zed Books Ltd.

Voice of America (2006). "CAR Government Refuses Rebel Demand for Negotiations." Vuković, Siniša (2012). "Coping with Complexity: Analyzing Cooperation and Coordination in Multiparty Mediation Processes." International Negotiation 17, 2: 265-293. Wanis-St. John, Anthony and Darren Kew (2008). "Civil Society and Peace Negotiations: Confronting Exclusion." International Negotiation 13, 1: 11-36.

Weidmann, Nils B (2016). "A Closer Look at Reporting Bias in Conflict Event Data." American Journal of Political Science 6o, 1: 206-218.

Xinhua News Agency (1998). "Burundi Conflict Parties Content with Peace Talks."

Zanker, Franzisca (2014). "Legitimate Representation: Civil Society Actors in Peace Negotiations Revisited." International Negotiation 19, 1: 62-88.

Zunes, Stephen (1994). "Unarmed Insurrections against Authorian Governments in the Third World: A New Kind of Revolution." Third World Quarterly 15, 3: 403-426. 